\title{
Perencanaan Arsitektur Enterprise Desa Dengan Kerangka Kerja TOGAF ADM
}

\author{
Zanuar Rifa'i[ ${ }^{1]^{*}}$, Trias Bratakusuma ${ }^{[2]}$, Ratna Arvianti $^{[3]}$ \\ Sistem Informasi, Ilmu Komputer ${ }^{[1],[2],[3]}$ \\ Universitas Amikom Purwokerto \\ Jl. Let. Jend. Pol. Soemarto Purwokerto \\ zanuar.rifai@amikompurwokerto.ac.id ${ }^{[1]}$, brata@amikompurwokerto.ac.id ${ }^{[2]}$, arvianti.ratna09@gmail.com ${ }^{[3]}$
}

\begin{abstract}
The village of Pageraji is one of the village governments located in the western capital of Banyumas Regency. The process of administration services in Pageraji Village still uses conventional systems. Based on the analysis of the problem, researchers will make planning the enterprise architecture to know in detail the business process and the stages in the Pageraji Village hall. The method used is TOGAF ADM by using four stages, namely architecture stage of vision, business architecture, information system architecture, and technology architecture. The overall analysis of the results of 4 phases of TOGAF ADM obtained the conformity between architectural needs and the recommended architecture seen from the results of analysis of requirement management with the four stages of TOGAF ADM. The results of this study are architectural planning companies.
\end{abstract}

Keywords- Enterprise Architecture, Pageraji village, village government, performance, TOGAF ADM

Abstrak-- Desa Pageraji adalah salah satu pemerintah desa yang terletak di sebelah barat Ibu Kota Kabupaten Banyumas. Proses pelayanan administrasi di Desa Pageraji masih menggunakan sistem konvensional. Berdasarkan analisis permasalahan, maka peneliti akan membuat perencanaan arsitektur enterprise guna mengetahui secara detail proses bisnis beserta tahapannya di Balai Desa Pageraji. Adapun metode yang digunakan adalah TOGAF ADM dengan menggunakan empat tahap yaitu tahap arsitektur visi, arsitektur bisnis, arsitektur sistem informasi, dan arsitektur teknologi. Analisis hasil keseluruhan 4 fase TOGAF ADM diperoleh adanya kesesuaian antara kebutuhan arsitektur dengan arsitektur yang direkomendasikan dilihat dari hasil analisis requirement management dengan empat tahap TOGAF ADM tersebut. Hasil dari penelitian ini adalah adanya perencanaan arsitektur enterprise.

Kata Kunci Arsitektur Enterprise, Desa Pageraji, Pemerintah Desa, Kinerja, TOGAF ADM

\section{PENDAHULUAN}

Desa merupakan salah satu otonom yang berada pada level terendah dari hierarki otonomi daerah di Indonesia[1]. Berdasarkan Pasal 1 angka 1 Undang-Undang Nomor 6 Tahun 2014, Desa adalah kesatuan masyarakat hukum yang memiliki batas wilayah yang berwenang untuk mengatur dan mengurus urusan pemerintahan, kepentingan masyarakat setempat berdasarkan prakarsa masyarakat, hak asal usul, dan atau untuk hak tradisional yang diakui dan dihormati dalam sistem pemerintahan Negara Kesatuan Republik Indonesia[2].

Pemerintahan desa berdasarkan Peraturan Pemerintah Nomor 47 Tahun 2015 adalah penyelenggara urusan pemerintahan dan kepentingan masyarakat setempat dalam sistem pemerintahan Negara Kesatuan Republik Indonesia[3]. Pemerintahan desa terdiri dari pemerintah desa dan BPD (Badan Permusyawaratan Desa). Adapun fungsi dari pemerintah desa yaitu melakukan administrasi desa yang dilakukan oleh kepala desa, perangkat desa dan warga desa itu sendiri.

Pemerintahan desa berdasarkan Peraturan Pemerintah Nomor 47 Tahun 2015 adalah penyelenggara urusan pemerintahan dan kepentingan masyarakat setempat dalam sistem pemerintahan Negara Kesatuan Republik Indonesia Pemerintahan desa terdiri dari pemerintah desa dan BPD (Badan Permusyawaratan Desa). Adapun fungsi dari pemerintah desa yaitu melakukan administrasi desa yang dilakukan oleh kepala desa, perangkat desa dan warga desa itu sendiri[3].

Desa Pageraji merupakan salah satu pemerintahan desa yang terletak di sebelah barat ibu kota Kabupaten Banyumas dengan jarak kurang lebih $9 \mathrm{Km}$ yang terdiri dari dataran rendah dan dataran tinggi. Di sebelah utara berbatasan dengan Desa Langgongsari, sebelah timur berbatasan dengan Desa Langgongsari dan Desa Pejogol, sebelah selatan berbatasan dengan Desa Jatisaba, Desa Kasegeran, dan Desa Sudimara, sebelah barat berbatasan dengan Desa Cilongok, dan Desa Pernasidi. Desa Pageraji memiliki luas daerah 640, 565 hektar (Ha) atau $6.4 \mathrm{Km} 2$.

Secara administratif Desa Pageraji termasuk dalam wilayah Kecamatan Cilongok dan berjarak kurang lebih $3 \mathrm{Km}$ dari Ibu Kota Kecamatan. Secara kewilayahan Desa Pageraji terdiri dari 3 dusun, $10 \mathrm{RW}$ (Rukun Warga) dan 59 RT (Rukun Tetangga). Jumlah penduduk Desa Pageraji sampai dengan 31 Desember 2018 sebanyak 10.766 orang dengan jumlah penduduk laki-laki sebanyak 5.537 orang, jumlah penduduk perempuan sebanyak 5.229 orang, dan jumlah kepala keluarga sebanyak 3.169 KK (Kepala Keluarga).

Desa Pageraji merupakan salah satu desa yang sudah mengimplementasikan teknologi informasi berupa seperangkat komputer untuk membantu dalam proses administrasinya. Proses pelayanan administrasi desa dilakukan di Balai Desa Pageraji, dimana perangkat desa bertugas melayani proses 
administrasi yang dibutuhkan oleh warga desa, sedangkan warga desa mendatangi kantor Balai Desa untuk melakukan serangkaian prosedur untuk mendapatkan layanan yang dibutuhkan.

Berdasarkan observasi bahwa dalam melakukan proses pelayanan administrasi di Balai Desa Pageraji masih menggunakan sistem konvensional yaitu dengan memasukkan data kedalam komputer atau mencatat proses pelayanan pada kertas atau buku secara manual. Misalnya dalam pembuatan surat pengajuan hutang ke Bank, surat pengantar menikah, surat jaminan kesehatan daerah, surat pengantar izin hajatan, dan surat keterangan tanah masih dibuat dengan mengetikan pada aplikasi microsoft word. Selain itu pencatatan surat masuk dan surat keluar masih dituliskan di dalam buku besar secara manual.

Kondisi tersebut menyebabkan beberapa permasalahan seperti kurangnya efisiensi waktu, salah memasukkan data, dan terjadinya kesalahan penulisan. Meskipun di Desa Pageraji sudah memiliki aplikasi SMARD (Sistem Manajemen Administrasi Desa) yang diakses oleh satu orang kepala urusan tata usaha dan umum beserta satu orang stafnya dan satu orang sekretaris desa yang mengakibatkan lambatnya proses aplikasi saat digunakan. Selain digunakan tiga orang tersebut terdapat kendala lain seperti server down. Server down diakibatkan oleh kegiatan perawatan infrastruktur dari provider yang dilakukan dua kali dalam satu bulan.

Efisiensi waktu sangat dibutuhkan untuk mempercepat proses pelayanan seperti pembuatan surat pengantar dan pembuatan surat keterangan. Data yang valid menjadi bukti otentik yang dapat dipertanggungjawabkan. Jika data yang dimasukkan tidak sesuai dapat menyebabkan data yang dimasukkan tidak tersimpan bahkan saat dicetak data tidak muncul. Dalam proses update identitas NIK (Nomor Induk Kependudukan) dapat dilakukan secara langsung di dinas kependudukan dan pencatatan sipil dengan persyaratan membawa surat pengantar dari desa dan dari kecamatan[4].

Desa merupakan salah satu otonom yang berada pada level terendah dari hierarki otonomi daerah di Indonesia[5]. Desa Pageraji merupakan salah satu pemerintahan desa yang terletak di sebelah barat ibu kota Kabupaten Banyumas. Desa Pageraji merupakan salah satu desa yang sudah mengimplementasikan teknologi informasi berupa seperangkat komputer untuk membantu dalam proses administrasinya namun dalam melakukan proses pelayanan administrasi di Desa Pageraji masih menggunakan sistem konvensional yaitu dengan memasukkan data kedalam komputer atau mencatat proses pelayanan pada kertas atau buku secara manual. Berdasarkan analisis permasalahan di atas, maka peneliti akan membuat perencanaan arsitektur enterprise guna mengetahui secara detail proses bisnis beserta tahapannya di Balai Desa pageraji. Sehingga perencanaan yang dibuat sesuai dengan kebutuhan. Banyak proses bisnis di dalam organisasi yang terpecah-pecah dan tidak sesuai. Arsitektur enterprise membantu pemerintah Desa Pageraji mengintegrasikan proses bisnis yang ada agar berjalan dengan efektif dan efisien. Adapun metode yang digunakan dalam penelitian ini adalah TOGAF ADM.

\section{METODE PENELITIAN}

Metode yang digunakan dalam penelitian Perencanaan Arsitektur Enterprise Pada Desa Pageraji Menggunakan TOGAF ADM ini adalah berbentuk dokumen yang didalamnya terdapat data, diantaranya data gambaran umum Desa Pageraji Tahun 2018 yang berisikan gambaran kondisi geografis, gambaran umum demografis, dan kondisi ekonomi (pertanian, peternakan, perikanan, perdagangan, industri, dan jasa) di Desa Pageraji. Data Rencana Pembangunan Jangka Menengah Desa (RPJMDes) Desa Pageraji yang didalamnya berisikan data profil Desa Pageraji, struktur organisasi di Balai Desa Pageraji, visi dan misi Desa Pageraji, potensi dan masalah Desa Pageraji.

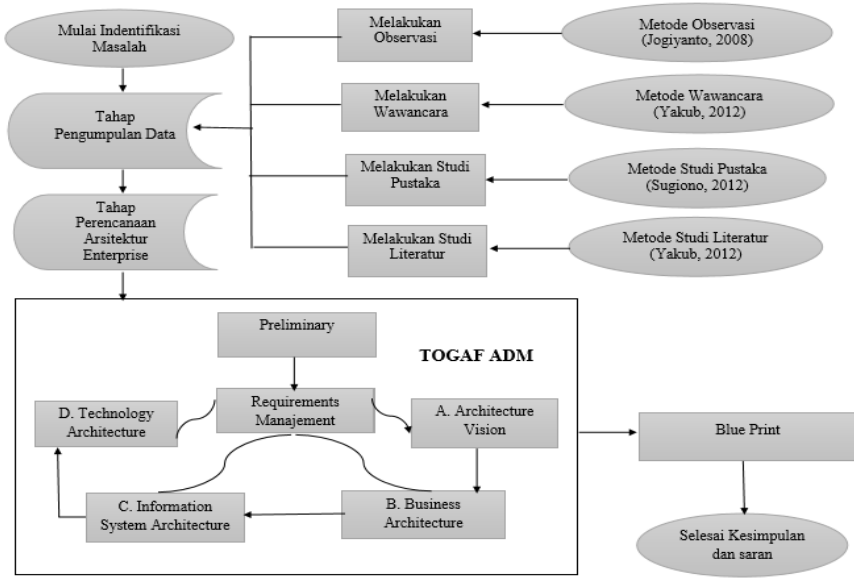

Gambar 1. Kerangka Berfikir Penelitian[6]

Kerangka berfikir yang terdiri dari tahapan di atas dapat dijelaskan seperti di bawah ini:

\section{A. Tahap Identifikasi Masalah}

Pada tahap ini, peneliti melakukan identifikasi masalah yang terjadi, membuat kerangka permasalahan serta merumuskan solusi untuk memecahkan permasalahan yang telah dihadapi pada Desa Pageraji.

\section{B. Tahap Pengumpulan Data}

Pada tahap pengumpulan data ini, data yang digunakan pada penelitian ini merupakan data primer dan data sekunder. Data primer yang didapat oleh peneliti yang berasal dari hasil observasi langsung ke Balai Desa Pageraji, serta wawancara langsung dengan Ibu Rina Widiastuti selaku sekretaris di Balai Desa Pageraji. Data sekunder yang didapat peneliti berasal dari studi pustaka dan studi literatur beberapa penelitian sebelumnya.

\section{Tahap Perencanaan Arsitektur Enterprise (TOGAF ADM)}

Metode perancangan arsitektur enterprise di Desa Pageraji menggunakan metodologi TOGAF ADM. Ada empat tahap dalam metodologi TOGAF ADM yang akan digunakan peneliti diantaranya[7][8][9][10][11]:

\section{1) Phase Preliminary}

Tahap ini bertujuan untuk mengidentifikasi $5 \mathrm{~W}+1 \mathrm{H}$ (what, who, when, where, why, dan how) dalam perencanaan arsitektur enterprise dan menentukan prinsip-prinsip 
perencanaan arsitektur enterprise yang disusun menggunakan principle catalog. Tools yang digunakan pada tahap preliminary yaitu principle catalog.

\section{2) Requirements Management}

Tahap ini bertujuan untuk menentukan kebutuhan arsitektur enterprise di Desa Pageraji, Kecamatan Cilongok, Kabupaten Banyumas, kebutuhan itu disimpan kemudian dimasukkan ke dalam tahap yang sesuai. Sumber daya harus dikembangkan dalam tahap ini adalah skenario aktivitas. Skenario aktivitas mencakup aktivitas dan permasalahan dalam organisasi. Tools yang digunakan pada tahap requirement management yaitu Metode fishbone analysis (analisis tulang ikan).

\section{3) Phase A: Architecture Vision}

Tahap ini bertujuan untuk menyamakan pandangan mengenai pentingnya perencanaan arsitektur enterprise untuk mencapai tujuan perusahaan atau organisasi dan menentukan lingkup perencanaan strategis yang dikembangkan. Beberapa hal yang perlu diperhatikan pada awal siklus arsitektur untuk menciptakan visi arsitektur yaitu memvalidasi konteks, serta membuat pernyataan arsitektur proses yang disetujui. Tools yang digunakan pada tahap arsitektur visi yaitu Value Chain Diagram.

\section{4) Phase B: Business Architecture}

Tahapan ini berisi bagaimana proses pada strategi bisnis, organisasi, dan informasi aktivitas utama. Arsitektur bisnis digunakan sebagai sarana untuk menunjukkan nilai dan alur aktivitas yang diusulkan sesuai dengan kebutuhan stakeholdernya. Tools yang digunakan pada tahap arsitektur bisnis yaitu BPMN (Business Process Model and Notation).

\section{5) Phase C: Information Sistem Architecture}

Tahap ini bertujuan mengembangkan arsitektur sistem informasi dalam hal data dan aplikasi yang terkait. Hal ini menggambarkan bagaimana arsitektur sistem informasi dapat menjalankan arsitektur visi dan arsitektur bisnis dapat memenuhi kebutuhan stakeholder. Tahap ini menekankan bagaimana arsitektur sistem informasi dirancang meliputi arsitektur data dan arsitektur aplikasi yang akan digunakan di Desa Pageraji. Tools yang digunakan pada arsitektur aplikasi yaitu Metode BSP (Business Sistem Planning).

\section{6) Phase D: Technology Architecture}

Tahap ini bertujuan mengembangkan teknologi sehingga dapat menerapkan visi arsitektur guna menjawab keinginan stakeholder. Dalam tahap ini diidentifikasi komponenkomponen arsitektur yang akan ada sebagai target arsitektur teknologi Tools yang digunakan pada arsitektur teknologi yaitu Basic Network Diagram

\section{7) Kesimpulan dan Saran}

Pada tahap ini merupakan tahap akhir dalam penelitian ini. Akan dibuat beberapa kesimpulan dari hasil penelitian dan juga saran yang diharapkan dapat berguna untuk pengembangan penelitian selanjutnya.

\section{PEMBAHASAN}

\section{A. Preliminary Phase}

Fase ini merupakan tahapan persiapan yang bertujuan untuk mengidentifikasi $5 \mathrm{~W}+1 \mathrm{H}$ (what, who, why, when where dan how) dan menentukan prinsip-prinsip perencanaan arsitektur enterprise.

TABEL 1. Identifikasi $5 \mathrm{~W}+1 \mathrm{H}$

\begin{tabular}{|c|c|c|}
\hline No & Driver & Deskripsi \\
\hline 1. & What & $\begin{array}{l}\text { a. Objek: Ruang lingkup arsitektur enterprise di } \\
\text { Desa Pageraji, Kecamatan Cilongok, } \\
\text { Kabupaten Banyumas. } \\
\text { b. Deskripsi: Membuat perencanaan model } \\
\text { arsitektur enterprise. }\end{array}$ \\
\hline 2. & Who & $\begin{array}{l}\text { a. Objek: Siapa saja pelaku utama yang terlibat } \\
\text { dalam pemodelan arsitektur enterprise ini. } \\
\text { b. Deskripsi: } \\
\text { Pembuat perencanaan: Peneliti } \\
\text { Tanggung Jawab : Perangkat Desa }\end{array}$ \\
\hline 3. & When & $\begin{array}{l}\text { a. Objek: Waktu penelitian perencanaan } \\
\text { arsitektur enterprise dengan framework } \\
\text { TOGAF ADM. } \\
\text { b. Deskripsi: Agustus - Desember } 2019 .\end{array}$ \\
\hline 4. & Where & $\begin{array}{ll}\text { a. } & \text { Objek: Menunjukkan lokasi kerja dan } \\
\text { organisasi. }\end{array}$ \\
\hline 5. & Why & $\begin{array}{ll}\text { a. } & \text { Objek: Mengapa arsitektur enterprise } \\
\text { dibangun. } \\
\text { b. Deskripsi: Untuk membuat rencana arsitektur } \\
\text { enterprise yang dapat menyelaraskan antara } \\
\text { arsitektur bisnis organisasi dengan kebutuhan } \\
\text { sistem dan teknologi informasi, sehingga } \\
\text { dapat membuat aktivitas atau proses bisnis } \\
\text { berjalan secara efektif dan efisien, serta } \\
\text { meningkatkan pelayanan di Balai Desa } \\
\text { Pageraji kepada masyarakat. }\end{array}$ \\
\hline 6. & How & $\begin{array}{l}\text { a. Objek: Menentukan bagaimana perencanaan } \\
\text { arsitektur enterprise dibuat. } \\
\text { b. Deskripsi: Menggunakan metodologi TOGAF } \\
\text { ADM dengan mengambil } 4 \text { tahapan yaitu, } \\
\text { arsitektur visi, arsitektur bisnis, arsitektur } \\
\text { sistem informasi, dan arsitektur teknologi. }\end{array}$ \\
\hline
\end{tabular}

Tabel 1. di atas menjelaskan identifikasi objek-objek yang yang terlihat di Balai Desa Pageraji, Kecamatan Cilongok, Kabupaten Banyumas mengacu pada beberapa prinsip perencanaan arsitektur enterprise yang disesuaikan dengan pernyataan what, who, when, where, why, dan how. Berikut dari hasil identifikasi objek-objek dan deskripsi pada tabel 3.1 dipetakan dalam principle catalog untuk perencanaan arsitektur enterprise di Desa Pageraji, Kecamatan Cilongok, Kabupaten Banyumas.

Tabel 2. principle catalog menjelaskan prinsip-prinsip acuan dalam pengambilan keputusan arsitektur pada bidang sistem dan teknologi informasi, menentukan struktur dan komposisi dari komponen-komponen arsitektur, menentukan kriteria pemilihan teknologi, serta menjadi acuan dalam perencanaan dan pengimplementasian arsitektur enterprise. 
TABEL 2. Principle Catalog

\begin{tabular}{|c|c|c|}
\hline No & Prinsip & Tujuan \\
\hline 1. & $\begin{array}{l}\text { Arsitektur } \\
\text { enterprise yang } \\
\text { dibuat harus sesuai } \\
\text { dengan tujuan, } \\
\text { aktivitas atau proses } \\
\text { bisnis, serta tugas } \\
\text { pokok dan fungsi di } \\
\text { Balai Desa Pageraji } \\
\text { Kecamatan } \\
\text { Cilongok, } \\
\text { Kabupaten } \\
\text { Banyumas. } \\
\end{array}$ & $\begin{array}{l}\text { a. Mendukung aktivitas atau proses } \\
\text { bisnis dari tupoksi di Balai Desa } \\
\text { Pageraji, Kecamatan Cilongok, } \\
\text { Kabupaten Banyumas } \\
\text { b. Memperkuat hubungan antara } \\
\text { infrastruktur dan aktivitas atau } \\
\text { proses bisnis sehingga } \\
\text { memudahkan penyelerasan } \\
\text { aktivitas atau proses bisnis ketika } \\
\text { terjadi perubahan. }\end{array}$ \\
\hline 2. & $\begin{array}{l}\text { Arsitektur } \\
\text { enterprise yang } \\
\text { dibuat harus mudah } \\
\text { dikelola dan } \\
\text { digunakan (user } \\
\text { friendly). }\end{array}$ & $\begin{array}{l}\text { a. Memudahkan dalam penggunaan } \\
\text { akan meningkatkan efektifitas dari } \\
\text { aktivitas atau proses bisnis yang } \\
\text { dilakukan serta meningkatkan } \\
\text { efisiensi sumber daya. } \\
\text { b. Membantu kerjasama antar bagian } \\
\text { pada organisasi. }\end{array}$ \\
\hline 3. & $\begin{array}{l}\text { Arsitektur enterprise } \\
\text { yang dikembangkan } \\
\text { harus mendukung } \\
\text { kesinambungan } \\
\text { aktivitas atau proses } \\
\text { bisnis. }\end{array}$ & $\begin{array}{l}\text { a. Meminimalisir gangguan pada } \\
\text { sistem yang dapat menghambat } \\
\text { operasional aktivitas atau proses } \\
\text { bisnis. }\end{array}$ \\
\hline 4. & $\begin{array}{l}\text { Arsitektur enterprise } \\
\text { yang dikembangkan } \\
\text { harus aman }\end{array}$ & $\begin{array}{l}\text { a. Tidak membahayakan keamanan } \\
\text { dan kerahasiaan data, serta } \\
\text { teknologi yang ada dan Kearsipan } \\
\text { di Balai Desa Pageraji. } \\
\text { b. Meminimalisir dampak dari } \\
\text { bencana. } \\
\text { c. Mampu bertahan dari serangan } \\
\text { malware, hack, dan sebagainya }\end{array}$ \\
\hline 5. & $\begin{array}{l}\text { Arsitektur enterprise } \\
\text { yang dirancang } \\
\text { harus memudahkan } \\
\text { dalam penambahan } \\
\text { dan Pengembangan } \\
\text { di masa depan. }\end{array}$ & $\begin{array}{l}\text { a. Memudahkan respon yang lebih } \\
\text { cepat apabila ada perubahan atau } \\
\text { untuk mengikuti perubahan tren IT. } \\
\text { b. Mengefisiensi biaya pengembangan } \\
\text { dan pemeliharaan infrastruktur }\end{array}$ \\
\hline 6. & $\begin{array}{l}\text { Aplikasi dengan } \\
\text { data yang mudah } \\
\text { diakses. }\end{array}$ & 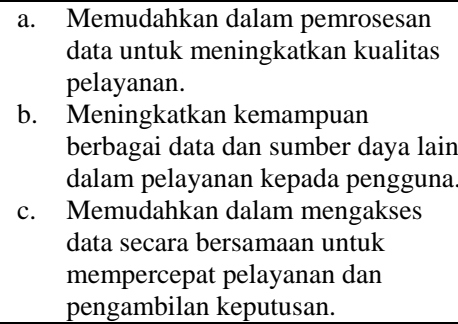 \\
\hline 7. & $\begin{array}{l}\text { Data harus konsisten } \\
\text { di semua bagian dan } \\
\text { data harus dikelola } \\
\text { sebagai suatu aset. }\end{array}$ & $\begin{array}{l}\text { a. Meningkatkan ketersediaan data } \\
\text { bagi pihak yang membutuhkan. } \\
\text { b. Memudahkan pengelolaan dan } \\
\text { pertanggungjawaban terhadap } \\
\text { kualitas data. }\end{array}$ \\
\hline 8. & $\begin{array}{l}\text { Keamanan dan } \\
\text { kerahasiaan data. }\end{array}$ & $\begin{array}{ll}\text { a. } & \text { Melindungi data dari akses yang } \\
\text { dilakukan pihak-pihak yang tidak } \\
\text { berwenang. }\end{array}$ \\
\hline
\end{tabular}

\section{B. Requirement Manajement}

Tahap ini bertujuan untuk menentukan kebutuhan arsitektur enterprise di Desa Pageraji, Kecamatan Cilongok, Kabupaten Banyumas, kebutuhan itu disimpan kemudian dimasukkan ke dalam tahap yang sesuai. Sumber daya harus dikembangkan dalam tahap ini adalah skenario aktivitas yang mencakup aktivitas dan permasalahan dalam organisasi.

Aktivitas dan permasalahan dalam organisasi digambarkan dengan menggunakan metode fishbone analysis (analisis tulang ikan). Dalam metode ini akar permasalahan dirumuskan dalam prinsip $5 \mathrm{M}+2$ atau dikategorikan dalam 7 kategori yaitu manpower, machine, method, material, media, motivation, dan money.

\section{a) Manpower (Tenaga Kerja)}

Segala permasalahan yang berkaitan dengan aspek tenaga kerja dilihat dari aspek lemahnya pengetahuan, kurangnya keterampilan, kekuatan fisik, lambatnya kinerja dari Pemerintah Desa Pageraji, Kecamatan Cilongok, Kabupaten Banyumas.

b) Machine (Mesin, Peralatan, dan Infrastruktur)

Segala permasalah yang berkaitan dengan aspek peralatan, atau tools lainnya dilihat dari pengadaan infrastruktur TIK desa dan pengadaan sarana dan prasarana di Desa Pageraji Kecamatan Cilongok, Kabupaten Banyumas.

c) Methods (Metode dan Prosedur Kerja)

Segala permasalah berkaitan dengan metode dan prosedur kerja, dilihat dari prosedur kerja yang tidak ada, tidak jelas, sulit dipahami, dan tidak memiliki standar yang sesuai dengan tugas dan fungsi pokok sebagai perangkat desa.

d) Materials (Material Bahan Baku Utama, dan Bahan Baku Pendukung)

Segala permasalahan yang berkaitan dengan ketersediaan aktivitas utama dan aktivitas pendukung yang ada di Desa Pageraji, Kecamatan Cilongok, Kabupaten Banyumas.

e) Media (Media, Lingkungan Kerja, dan Waktu Kerja)

Segala permasalahan yang berkaitan dengan tempat kerja (Balai Desa), waktu, dan lingkungan masyarakat di Desa Pageraji, Kecamatan Cilongok, Kabupaten Banyumas.

f) Motivation (Motivasi, dan Kompetensi)

Segala permasalahan yang berkaitan dengan sikap kerja, perilaku kerja, budaya kerja yang tidak benar ataupun tidak kondusif di Balai Desa Pageraji, Kecamatan Cilongok, Kabupaten Banyumas.

g) Money (Uang dan Financial)

Berkaitan dengan aspek keuangan, misalnya ketidak tersediaan anggaran dan penggunaan anggaran desa yang masih kurang optional.

Berdasarkan hasil pengamatan dan analisis yang dilakukan pada fishbone analysis (analisis tulang ikan), maka didapat beberapa permasalahan yang dialami oleh Pemerintah Desa Pageraji yaitu di bisang kepemerintahan desa, program pembangunan desa, pelayanan, keuangan, inventaris dan kearsipan serta monitoring dan evaluasi. Dan diusulkan solusi aktivitas dan solusi sistem informasi yang sesuai dengan permasalahan yang ada di Balai Desa Pageraji.

\section{Arsitektur Visi}

Tahap ini bertujuan untuk menyamakan pandangan mengenai pentingnya perencanaan arsitektur enterprise untuk mencapai tujuan perusahaan atau organisasi dan menentukan lingkup perencanaan strategis yang dikembangkan. Arsitektur 
visi menggambarkan aktivitas utama dan aktivitas pendukung di Balai Desa Pageraji yang digambarkan dengan value chain diagram dengan margin pelayanan prima.

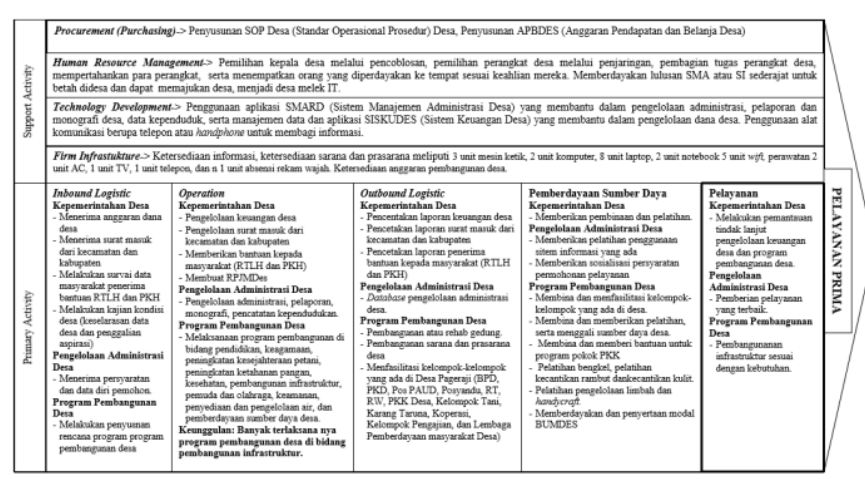

Gambar 2. Value Chain Diagram[11]

\section{Arsitektur Bisnis}

Tahap ini bertujuan mengembangkan target dari arsitektur visi yang menggambarkan bagaimana organisasi beroperasi untuk mencapai tujuan bisnis. Proses bisnis yang ada di Desa Pageraji, Kecamatan Cilongok, Kabupaten Banyumas digambarkan dengan BPMN (Business Process Model and Notation) yang terdiri dari proses bisnis aktivitas pemerintah Desa Pageraji, proses pembuatan surat keterangan, surat pengantar, dan program-program yang ada di Desa Pageraji.

\section{E. Arsitektur Sistem Informasi}

Tahap ini bertujuan mengembangkan arsitektur sistem informasi dalam hal data dan aplikasi yang terkait yang menekankan bagaimana arsitektur sistem informasi dirancang meliputi arsitektur data dan arsitektur aplikasi yang akan digunakan di Desa Pageraji. Pada tahap ini digambarkan menggunakan metode BSP (Business System Planning).

\section{F. Arsitektur Data}

Tahap ini dilakukan dengan memodelkan data yang berkaitan dengan proses bisnis dan organisasi serta menentukan siapa yang mempunyai tangung jawab utama dan pembuat keputusan, keterlibatan utama, dan mempunyai beberapa keterlibatan saja.

TABEL 3. Hubungan Kelas Data dengan Proses

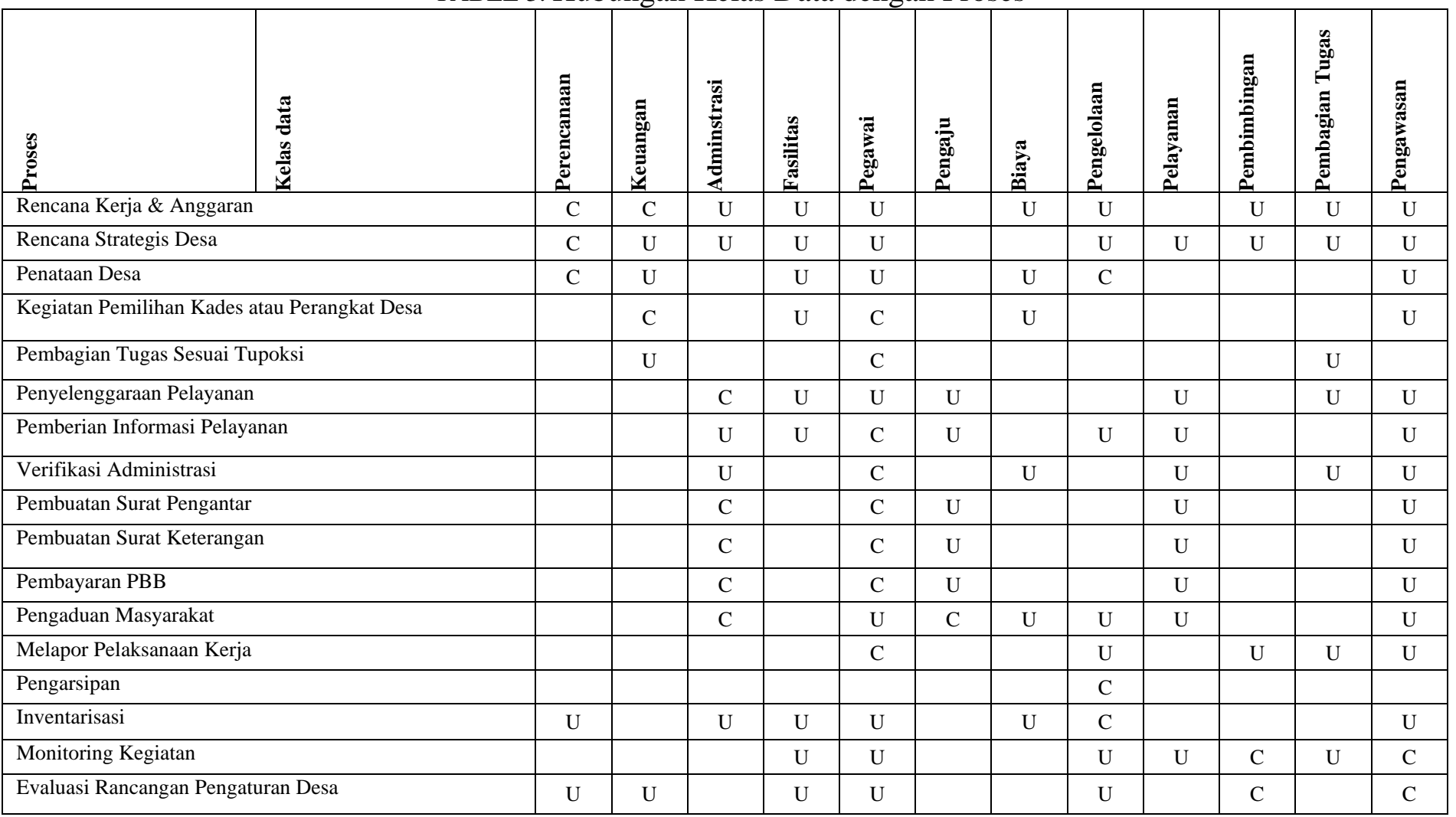


G. Arsitektur Aplikasi

Tahap ini menjelaskan hubungan kelas data dengan proses, dimana menggambarkan siapa yang berperan dalam proses pembuatan dan siapa yang menggunakan. C (create) untuk menggambarkan siapa yang membuat dan U (use) siapa yang menggunakan. Setelah menentukan siapa yang akan membuat dan siapa yang akan menggunakan nantinya, kemudian mengelompokan berdasarkan proses dan kelas data. Menentukan aliran data, membuat aliran data, dan diperoleh gambaran arsitektur aplikasi yang dibutuhkan di Desa Pageraji.

TABEL 4. Penataan Kembali Grafik Arsitektur Aplikasi

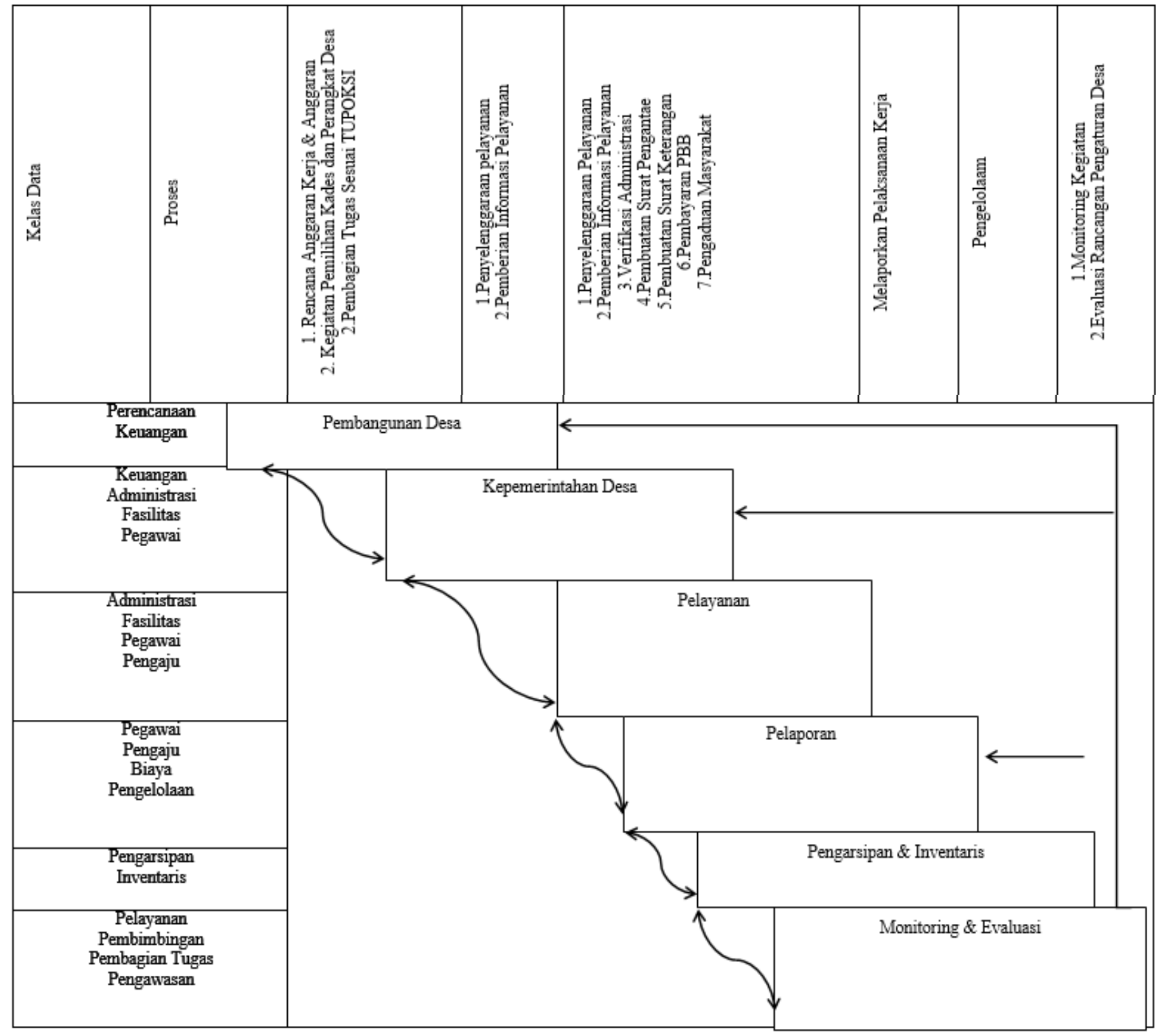


Dari hasil pendefinisian proses bisnis, kemudian menggambarkan hubungan kelas data dengan proses, mengelompokkan proses atau kelas data, menentukan aliran data, membuat aliran data pembuatan arsitektur informasi dan pengaturan kembali grafik arsitektur informasi diperoleh gambaran portofolio arsitektur sistem informasi berupa modul pembangunan desa, modul kepemerintahan desa, modul pelayanan, modul pelaporan, modul pengarsipan dan inventaris, dan modul monitoring dan evaluasi. Berikut seperti gambar dibawah ini:

TABEL 5. Portofolio Aplikasi

\begin{tabular}{|l|l|}
\hline \multicolumn{2}{|c|}{ Portofolio Aplikasi } \\
\hline $\begin{array}{l}\text { Dodul Pembangunan } \\
\text { Modul Pelayanan }\end{array}$ & Modul Kepemerintahan Desa \\
\hline $\begin{array}{l}\text { Modul Pengarsipan \& } \\
\text { Inventaris }\end{array}$ & Modul Pelaporan \\
\hline
\end{tabular}

\section{H. Aristektur Teknologi}

Tahap ini bertujuan mengembangkan teknologi sehingga dapat menerapkan visi arsitektur guna menjawab keinginan stakeholder. Dalam tahap ini diidentifikasi komponenkomponen arsitektur yang akan ada sebagai target arsitektur teknologi.

\section{1) Jaringan Usulan untuk Balai Desa Pageraji}

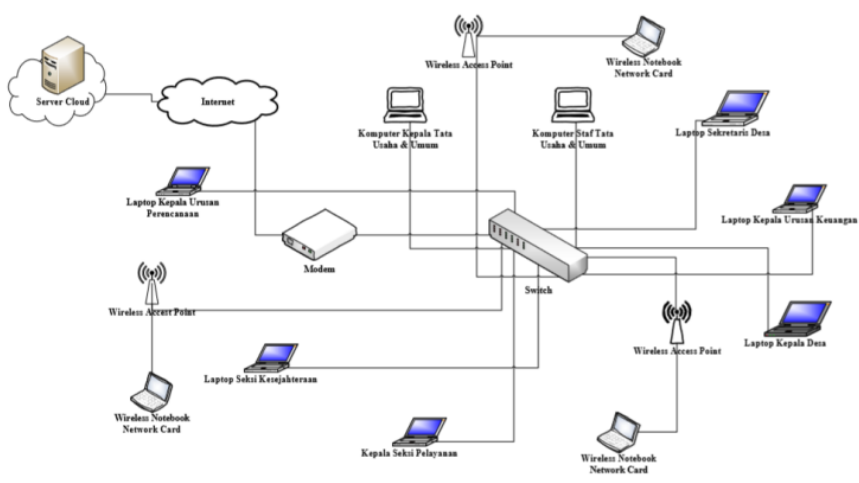

Gambar 5. Jaringan Usulan di Balai Desa Pageraji

Pada jaringan usulan di Balai Desa Pageraji digambar dengan menambah jumlah wifi. Dalam Kantor Balai Desa Pageraji ditambahkan jumlah wifinya menjadi 3 sehingga saat pengaksesan website tidak terkendala jaringan. Pembagian wifi melalui switch, kemudian segala aktivitas dikumpulkan dalam satu server yaitu di cloud server. Dengan harapan penyimpanan data di cloud server mengurangi biaya perawatan, penyediaan tempat yang sesuai standar penggunaan server fisik. Cloud server menampung semua kegiatan yang dilakukan di Kantor Balai Desa Pageraji. Ketika semua melakukan kegiatan, pelayanan, dan sebagainya data langsung di simpan dalam cloud server. Kepala desa dapat melakukan monitoring dan evaluasi kinerja pemerintah desa dengan mengakses cloud server melalui laptop kepala desa.

\section{2) Platform Teknologi}

\begin{tabular}{|c|c|c|c|}
\hline \multicolumn{2}{|c|}{ SIMADEJI (Sistem Informasi Desa Pageraji) } & \multirow{6}{*}{ 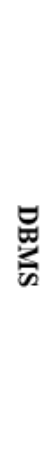 } & \multirow{6}{*}{ 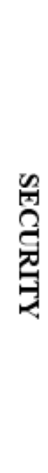 } \\
\hline $\begin{array}{c}\text { Modul } \\
\text { Pembangunan Desa }\end{array}$ & $\begin{array}{c}\text { Modul } \\
\text { Kepemerintahan Desa }\end{array}$ & & \\
\hline $\begin{array}{c}\text { Modul } \\
\text { Pelayanan }\end{array}$ & $\begin{array}{c}\text { Modul } \\
\text { Pelaporan }\end{array}$ & & \\
\hline $\begin{array}{c}\text { Modul } \\
\text { Kearsipan \& Inventaris }\end{array}$ & $\begin{array}{l}\text { Modul } \\
\text { Monitoring \& Evaluasi }\end{array}$ & & \\
\hline \multicolumn{2}{|c|}{ Portal Web } & & \\
\hline \multicolumn{2}{|c|}{ Web Client (PC, Laptop) } & & \\
\hline
\end{tabular}

Gambar 6. Platform Teknologi

Pada platform teknologi ini SIMADEJI (Sistem Informasi Desa Pageraji) menggabungkan modul-modul yang telah teridentifikasi dapat diakses oleh client melalui portal web. Akses pengguna terhadap aplikasi dengan menerapkan manajemen user. Dalam pengolahan data aplikasi didukung dengan DBMS (database management system) dan dalam keamanan aplikasi dilindungi oleh keamanan jaringan.

\section{KESIMPULAN}

Berdasarkan penelitian perencanaan arsitektur enterprise untuk meningkatkan kinerja pemerintah Desa Pageraji dengan kerangka kerja TOGAF ADM, maka dapat diambil kesimpulan bahwa analisis hasil keseluruhan 4 fase TOGAF ADM diperoleh adanya kesesuaian antara kebutuhan arsitektur dengan arsitektur yang direkomendasikan untuk pemerintah Desa Pageraji, Kecamatan Cilongok, Kabupaten Banyumas. Dilihat dari hasil analisis requirement management dengan empat tahap TOGAF ADM tersebut, sehingga di hasilkan cetak biru (blue print) yang membantu meningkatkan kinerja pemerintah desa dengan perencanaan aplikasi SIMADEJI (Sistem Informasi Desa Pageraji) yang mengintegrasikan modul pembangunan desa, modul kepemerintahan desa, modul pelayanan, modul pelaporan, modul pengarsipan dan inventaris, dan modul monitoring dan evaluasi.

\section{ACKNOWLEDGMENT}

Ucapan terimakasih penulis sampaikan kepada Universitas Amikom Purwokerto.

\section{REFERENCES}

[1] N. Hanif, "Pertumbuhan dan penyelenggaraan pemerintah desa," 2011.

[2] Kementrian Dalam Negeri, Undang-Undang nomor 6 tahun 2014 tentang desa. Jakarta, 2014.

[3] Kementrian Dalam Negeri., Peraturan pemerintah Republik Indonesia nomor 47 tahun 2015 tentang perubahan atas peraturan pemerintah nomor 43 tahun 2014 tentang peraturan pelaksanaan Undang-Undang nomor 6 tahun 2014 tentang desa. Indonesia, 2015.

[4] K. D. Negeri, Peraturan menteri dalam negeri Republik Indonesia nomor 2 tahun 2017 tentang standar pelayanan minimal desa. Jakarta, 2017. 
[5] Sugiman., Pemerintahan desa. Binamulia Hukum, 7th ed. 2018.

[6] I. P. Karunia, "Perancangan enterprise architecture menggunakan TOGAF architecture development method (Studi kasus: Dinas Tata Kota, Bangunan dan Pemukiman Kota Tangerang Selatan).,” 2015.

[7] A. A. Manuputty, A. D., dan Sari, "perencanaan arsitektur enterprise menggunakan TOGAF ADM (Architecture Development Method) pada Dinas Kesehatan Kota,” Sesindo., 2018.

[8] N. Safitri and R. Pramudita, "Pengembangan Kerangka Kerja Arsitektur Enterprise," Bina Insa. ICT J., vol. 4, no. 1, pp. 73-82, 2017.

[9] A. Sari and A. M. 2018, "Perencanaan Arsitektur Enterprise Menggunakan Togaf Adm (Architecture Development Method) Pada Dinas Kesehatan Kota," Sesindo 2018, no. November, 2018.

[10] D. Rusli and Y. Bandung, "Designing an enterprise architecture (EA) based on TOGAF ADM and MIPI," 2017 Int. Conf. Inf. Technol. Syst. Innov. ICITSI 2017 - Proc., vol. 2018-Janua, pp. 38-43, 2017.

[11] T. B. Kusuma and I. Setiawan, "Perancangan Strategis Sistem Informasi Menggunakan Togaf Architecture Development Method di PDAM Tirta Kerta Raharja Kabupaten Tangerang," Citisee, pp. 280$285,2017$. 